\title{
Resolution of Carotid Artery Stenosis After Medical Treatment: Case Report
}

\author{
Nobuhiko AokI, M.D. and Akihiro OIKAWA, M.D.
}

\begin{abstract}
Summary: A 61-year-old man presented wtih right-sided hemiparesis due to stenosis of the cervical internal carotid artery. He was conservatively treated by antiplatelet therapy and dietary management because of high-positioned stenosis, which is surgically hard to access, and because of rapid improvement of the symptoms. Reevaluation 9 months after the first angiography demonstrated complete disappearance of the carotid stenosis and resolution of the symptoms. The observation, though rare, in this case emphasizes the efficacy of antiplatelet therapy combined with dietary management for atherosclerotic disease. We discuss the mechanism of resolution of carotid stenosis.
\end{abstract}

\author{
Key words: \\ - cerebral infarction \\ - carotid artery stenosis \\ - atheromatous plaque \\ - antipaltelet therapy \\ - dietary management
}

Surg Cereb Stroke (Jpn) 27: 489-492, 1999

\section{Introduction}

There exists a definite racial difference in the incidence of extracranial carotid artery stenosis. ${ }^{8)}$ Generally, extracranial internal carotid artery lesions are less frequent and milder in Japanese stroke patients than in American stroke patients. ${ }^{5)}$ Recently, however, increase in the occurrence of this disease is noted in Japanese people. This is considered to be a consequence of the westernization of lifestyle in Japan, which is most prominently reflected in the daily diet. ${ }^{2) 9) 12)}$ We present a Japanese man who developed symptomatic stenosis of the extracranial internal carotid artery. This patient, who has long been living in the United States and taking an American style daily diet, is unique in that complete resolution of the symptomatic carotid artery stenosis on angiography was achieved after conservative treatment. The efficacy of dietotherapy is stressed, and the mechanism of this phenomenon is discussed.

\section{Case Report}

A 61-year-old, nonhypertensive Japanese man sudden- ly developed right-sided motor weakness when playing golf on October 16, 1994. Although his motor weakness was rapidly alleviated, he presented to our institute with a complaint of clumsiness of the right hand 2 days after the onset. He has been living in the United States for 32 years, and eating beefsteak as his main daily diet. On arrival at our outpatient clinic, neurological examination revealed clumsiness of the right hand and dysarthria. The remainders, including sensory and cranial nerve functions, were normal. Results of laboratory studies were normal, except for $234 \mathrm{mg} / \mathrm{dl}$ of triglyceride (normal male; 35-130 mg/dl). Cardiac ultrasonography did not show any abnormality. T2 weighted magnetic resonance (MR) imaging exhibited multiple infarctions in the corona radiata on the left side (Fig. 1). Cerebral angiography via femoral catheter demonstrated maximally $80 \%$ irregular stenosis of the internal carotid artery at the cervical region, beginning $3 \mathrm{~cm}$ above the carotid bifurcation (Fig. 2). A remarkable kinking of the internal carotid artery was also delineated.

Clinical course: Because his neurological deficits regressed rapidly, he was started with medical treatment. As antiplatelet therapy, $200 \mathrm{mg}$ of ticlopidine and $81 \mathrm{mg}$ of

Department of Neurosurgery, Tokyo Metropolitan Ohkubo Hospital (Received December 17, 1998) [Mailing address: Nobuhiko Aokı, M.D., Department of Neurosurgery, Tokyo Metrolopolitan Ohkubo Hospital, 44-1, Kabukicho 2-chome, Shinjuku-ku, Tokyo 160-8488, Japan] 


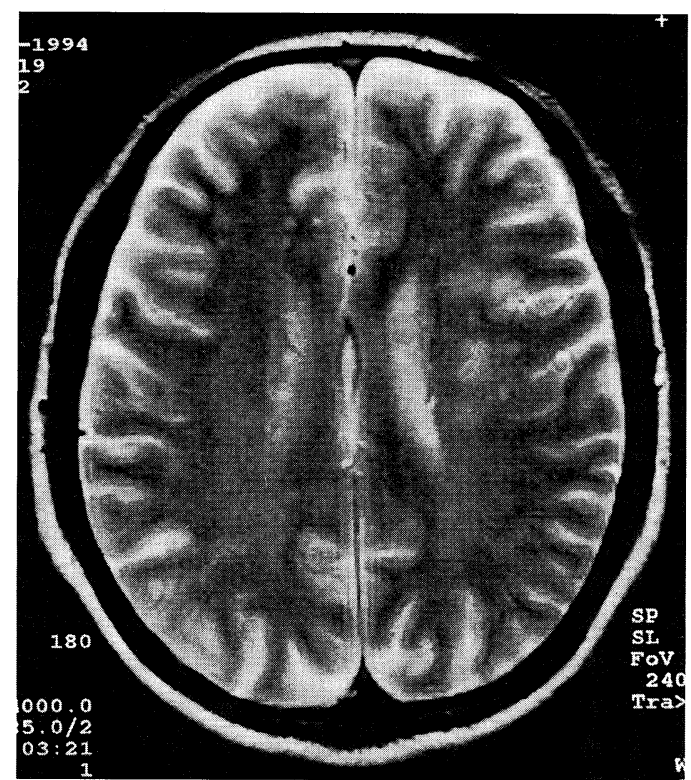

Fig. 1 T2 weighted magnetic resonance imaging, showing multiple infarctions in the corona radiata on the left side.

aspirin per day were administered. After discussing the availability of direct surgical intervention, carotid endarterectomy was not considered to be feasible because of the high-positioned stenosis of the carotid artery. Remarkable kinking of the carotid artery seemed to preclude the safety of transluminal angioplasty. Four days after admission, he developed right-sided hemiparesis and worsening of dysarthria, which subsided within two weeks. During hospitalization, rice and fish were mainly served as dietotherapy instead of beefsteak which had long been eaten as his main daily diet in the United State. After finishing the rehabilitation program, he returned to the United State with mild impairment of fine movement of the right fingers. In the United States, he continued the dietotherapy mainly composed of rice and fish, and medical treatment with $100 \mathrm{mg}$ of ticlopidine per day. On July 18, 1995, (nine months after the onset) he came to Japan for neurological and neuroradiological evaluation. No abnormality was revealed on neurological examination. Laboratory reevaluation including triglyceride was not performed at that time. Left carotid angiography demonstrated complete disappearance of the irregularity and stenosis of the carotid artery (Fig. 3). Pre-existing kinking of the carotid artery was unchanged. No recurrence of the neurological symptoms was confirmed by telephone interview two years after the onset.

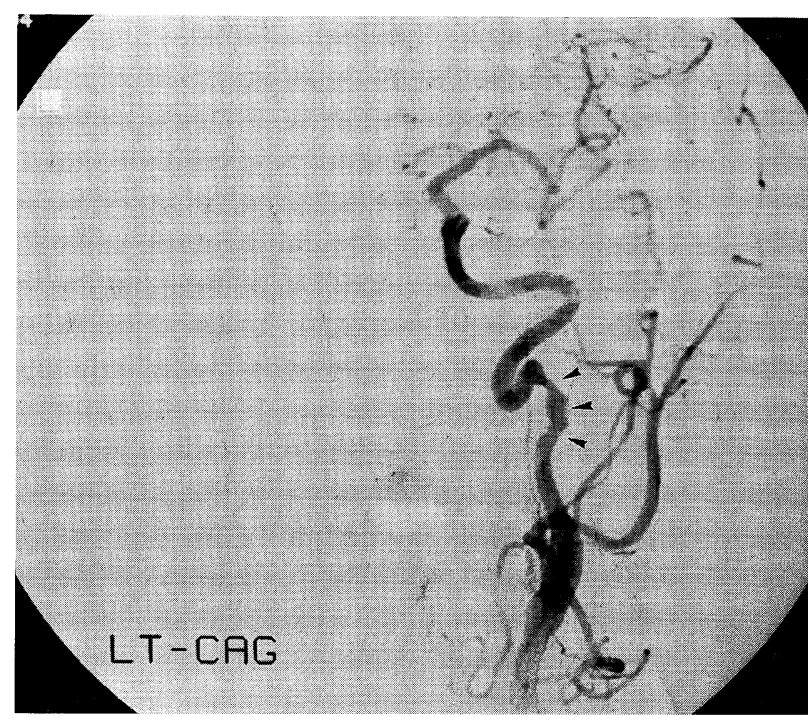

Fig. 2 Left carotid angiography on admission, demonstrating irregular stenosis of the internal carotid artery at the cervical region (arrowheads), beginning $3 \mathrm{~cm}$ above the carotid bifurcation. In addition, a remarkable kinking of the internal carotid artery is delineated.

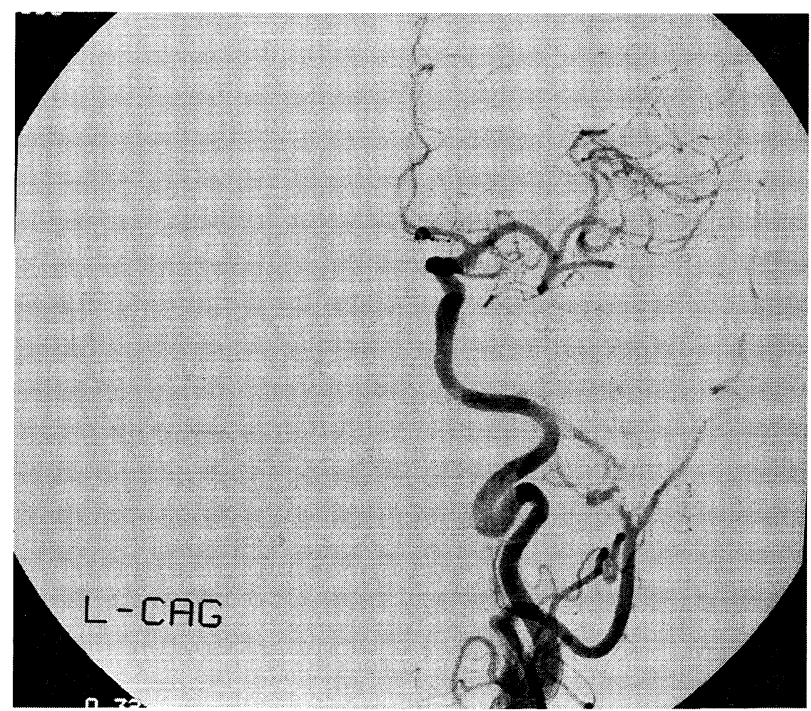

Fig. 3 Left carotid angiography nine months after the onset of the symptoms, revealing complete resolution of the carotid artery stenosis.

\section{Discussion}

Recent clinical randomized trials revealed much of contributory regarding the indication for carotid endarterctomy (CEA). ${ }^{4) 1014)}$ In addition, results of other investigations suggested that CEA was justified for symptomatic stenosis more than $70 \%$ and/or ulcerations, and for asymp- 
tomatic high-grade stenosis of the carotid artery. ${ }^{7) 12) 15)}$ It has been recognized that stenosis at the carotid bifurcation or the internal carotid artery is most commonly caused by atheromatous plaque formation. The course of this pathology is slowly progressive, but is occasionally associated with rapid development of intraplaque hemorrhage. $^{3) 11)}$ In this respect, the patient presented here seemed to have a unique clinical course. In view of the previous report by Bodosi et al., repeated angiograms revealed reduction of the size of the stenosis in four of 31 patients with stenosis of the distal segment of the internal carotid artery. ${ }^{1)}$ All patients received aspirin routinely, and at least one of their patients had stenosis at the cervical segment. They merely stated that regression of the stenosis occurred because the lesion had been formed by a mural thrombosis or an embolus which broken off in the clinical course. No further detailed analysis was described. Thus, it has been known that the high-positioned stenosis of the carotid artery, through very rare, regresses spontaneously or after antiplatelet therapy. ${ }^{1)}$ It is important, however, to elucidate the mechanism by which resolution of the carotid artery stenosis was obtained in our patient, because different pathogenesis is considered from that in the previous report. The present patient was complicated by remarkable kinking of the carotid artery, which itself also might be responsible for development of the symptom. In addition, the kinked carotid artery has been shown to be associated with atherosclerotic vascular diseases. ${ }^{6)}$ Although the carotid stenosis in this patient appeared to be caused by atherosclerosis on angiography, complete resolution of the stenosis after conservative treatment suggested that the lesion was not entirely composed of atheromatous plaques. It is plausible that the main part of the stenosis consists of intraplaque hematoma which has communication with the lumen of the artery through a rent of the plaque. Antiplatelet therapy and blood flow may contribute to dissolve the hematoma in the plaque and subsequently wash out the residual plaque, leading to regeneration of the intimal layer. Transient worsening of his symptoms during hospitalization may result from these phenomena. Retrospectively, it is possible that antiplatelet therapy in this setting may have a risk to induce artery-toartery embolism secondary to dislodgement of the hematoma and plaques.

There is a consensus that cervical carotid artery stenosis is less common in the Asian than in Caucasian population. Whereas the present patient is a Japanese, he has been living in the United States for 32 years and eating beefsteak as his main daily diet. This dietary style which had been previously popularized in the United States seems to closely related to the formation of the carotid artery stenosis in this patient. Antiplatelet therapy has been demonstrated to be effective for atheromatous thrombosis. ${ }^{13)}$ Beside this, daily diet is considered to have strong influence on the clinical course in patients with atherosclerotic diseases. Recently, Japanese daily diet has changed to an European-American style, leading to increase in the incidence of extracranial carotid artery stenosis in Japan. ${ }^{29) 12}$ Considering that the change of main daily diet from beefsteak to rice and fish may contribute to the resolution of the carotid artery stenosis in this patient, the importance of dietotherapy should be stressed again as the preventative strategy for atherosclerotic diseases.

\section{References}

1) Bodosi M, Gacs G, Merei FT: Stenosis of the distal segments of the internal carotid artery. Surg Neurol 16: 109-116, 1981

2) Endo T, Takaku A: Surgical procedures and indications for carotid endarterectomy. Neurosurgeons 13: 118-124, 1994 (in Japanese)

3) Endo S, Hirashima Y, Kurimoto M, et al: Acute pathologic features with angiographic correlations of the nearly or complete occluded lesions of the cervical carotid artery. Surg Neurol 46: 222-228, 1996

4) European Carotid Surgery Trialist's Collavolative Group: MRC European Carotid Surgery Trial: Interim, results for symptomatic patients with severe (70-99\%) or with mild (0-29\%) carotid stenosis. Lancet 337: 1235-1243, 1991

5) Kieffer SA, Takeya Y, Resch JA, et al: Racial differences in cerebrovascular disease: angiographic evaluation of Japanese and American populations. AJR Am J Roentgenol 101: 94-99, 1967

6) Leipzig TJ, Dohormann GJ: The tortuous or kinked carotid artery: pathogenesis and clinical considerations. A historical review. Surg Neurol 25: 478-486, 1986

7) Loftus CM, Hopkins LN: Paradoxical indications for carotid artery reconstruction. Neurosurgery 36: 99-100, 1995

8) Maxwell JG, Rutherford EG, Corington D, et al: Infrequency of blacks among patients having carotid endarteretomy. Stroke 120: 22-26, 1986

9) Nagao T, Sadoshima S, et al: Increase in extracranial atherosclerotic carotid lesions in patients with brain ischemia in Japan: an angiographic study. Stroke 25: 766-779, 1994

10) North American Symptomatic Carotid Endarterectmy Trial Collaborators: Beneficial effects of carotid endarerectomy in symptomatic patients with high-grade carotid stenosis. N Engl J Med 325: 445-453, 1991

11) Persson AV, Robichaux WT, Silverman M: The natural history of carotid plaque development. Arch Surg 118: 1048-1052, 1983

12) Shima K, Okada Y, Nishida M, et al: Surgical management of carotid occlusive disease. Hemodynamics of carotid artery, operative indication, surgical technique. Neurosurgeons 13: 109-117, 1994 (in Japanese)

13) Uchiyama $S$, Sone R, Nagayama $T$, et al: Combined therapy with low-dose aspirin and ticlopidine in cerebral ischemia. Stroke 20: 1643-1647, 1989 
14) The Ad Hoc Committee, American Heart Association: Guidelines for carotid endarteretomy. Circulation 91: 566-579, 1995

15) The Asymptomatic Carotid Atherosclerosis Study Group:
Study design for randomized prospective trial of carotid endarterectomy for asymptomatic atherosclerosis. Stroke 20: $844-849$, 1989

\section{内科治療にて完全消失の得られた頸部内頸動脈狭窄の 1 例}

青木信彦, 及川明博

都立大久保病院 脳神経外科

症例は左頸部内頸動脈狭窄によると考えられる軽度の右不全片 麻痺にて来院した 61 歳の日本人男性である。患者は 32 年間米国 にて生活し, beefsteakを主食としてきた. 内頸動脈狭窄は高位 に存在し外科治療は容易ではないことと, 症状の急速な改善がみ られたことから, 魚と野菜を中心とする食事療法と抗血小板薬の
投与が選択された。発症 9 力月後に再検したところ神経症状の消 失と, 血管撮影での内頸動脈狭窄の完全な消失が認められた。こ の症例の臨床経過は, 動脈硬化性疾患に対して, 症例によっては 食事療法と抗血小板療法がきわめて有用であることを示唆するも のであり, その機序についての検討を加えた。 